\title{
Extending the three-tier constructivist learning model for alternative delivery: ahead the COVID-19 pandemic in Nigeria
}

\author{
Arnold Adimabua Ojugo ${ }^{1}$, Rume Elizabeth Yoro ${ }^{2}$ \\ ${ }^{1}$ Department of Computer Science, Federal University of Petroleum Resources Effurun, Nigeria \\ ${ }^{2}$ Department of Computer Science, Delta State Polytechnic Ogwashi-Uku, Delta State, Nigeria
}

\begin{tabular}{|c|c|}
\hline Article Info & ABSTRACT \\
\hline Article history: & Constructivist theory defines a learning process whereby a learner denotes \\
\hline Received Apr 27, 2020 & $\begin{array}{l}\text { meaning for him/herself as he/she learns. Its challenges inform us that focus } \\
\text { and intervention needs to be given to our curricular and instructional }\end{array}$ \\
\hline Revised Jul 29, 2020 & material, so that we may have something to offer students in the next century \\
\hline Accepted Aug 8, 2020 & in terms of scientific development, drawing us into technological isolation. \\
\hline Keywords: & $\begin{array}{l}\text { science, technology, engineering and mathematics in tertiary institutions in } \\
\text { Delta State. We chose } 72 \text { institutions using quota sampling. To uphold the }\end{array}$ \\
\hline Alternative delivery & virtues of internationalization, results show we must devise strategies against \\
\hline Constructivism & $\begin{array}{l}\text { de-territorializing of knowledge. And thus, redefine educational goals to } \\
\text { meet globalization as a means of network and unification. Thus, }\end{array}$ \\
\hline Informatics & constructivism yields and apt description of both individual, group and \\
\hline Learning process & organizational adoption patterns of technology for teaching and learning \\
\hline Lifelong & across disciplines at the various schools and educational levels. It images \\
\hline Media literacy & exemplary practices for teaching, learning and research, highlighting \\
\hline Technology & $\begin{array}{l}\text { evidences that links technology integration, readability and quality students } \\
\text { learning. }\end{array}$ \\
\hline
\end{tabular}

This is an open access article under the CC BY-SA license.

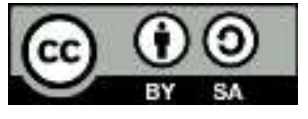

Corresponding Author:

Arnold Adimabua Ojugo

Department of Computer Science

Federal University of Petroleum Resources Effurun, Delta State, Nigeria

Email: ojugo.arnold@fupre.edu.ng

\section{INTRODUCTION}

Technology today, has become an integral culture in our society and the application of science to help us achieve societal goals and of generations to come [1]. Technology has become our heritage so that the mission of today's education ensure that students are scientifically prepared to navigate the technological changes of the information era [2]. Its goal thus, is to: (a) equip us adequately to adapt to societal changes, (b) provides us with basic literacy in science and its application of technology to everyday living, (c) equip us with the requisite attitude and skills needed for future endeavours, and (d) stimulate/enhance our creativity $[1,3]$. Education is transference of knowledge from a teacher to a learner, and usually within a physical setup called a school with confined spaces called classrooms. A classroom is an organized space in which learning can take place. It has 3-components: student(s), teacher(s) and administrator(s). Education is delivered via 2forms namely: (a) traditional pedagogy that adopts an oral, face-to-face paradigm with a teacher to a student, and (b) alternative delivery pedagogy that integrates technology allowing student to construct knowledge and new meaning from previous concept and/or belief. The latter, is more concerned with what a student learns, understands, and impacts with such knowledge (more than a teacher's input). This education integration of 
modern science and technology redirects its focus on technology of education (paradigm) and on educational support of technology (pedagogy) as in Figure 1 [3-5].

Ojugo et al [6] laments that science-tech education has not received the requisite attention, as it often misunderstood both by parents, educators and other stakeholders in Nigeria, who believe that sciencetech education is mainly targeted at students who cannot pursue academics. They posit that proper values must be placed to help the nation attain desired growth as industrialized nations employs skills from both the educated and technicians. In Nigeria today, the growth of tech is a sad reflection of the poor policies toward education and moreso, the poor quality and stigmatized attention given to science-tech education today [7]. To address these, proper values must be placed on the need for science-tech education and its misconception erased from the minds of all stakeholder. Science-tech education remains the bedrock for tech progress and growth. Campione et al [8] Nations, in the pursuit of prosperity must lay greater emphasis on science-tech; And [9] the fallen educational standard and tech backwardness, is attributed to variant educational system practiced in Nigeria. The advent of computers has seen improvements that encourage everyone to acquire considerable knowledge in science-tech in order to effectively harness the benefits offered by ICT [10].

Constructivism proposes an education environ that supports multiple interpretations or perspective to reality and knowledge construction amongst learner via a context-rich and experience-based activity cum classroom. It focuses on a learner's capability to construct knowledge via mental structures, experiences and beliefs that interpret events and objects. This paradigm tasks learners on real world relevance, integrated across curriculum that yields the required level of difficulty or learner involvement. It is rather impossible for a learner to become masters of all content areas [11]. For its instruction to be anchored on a meaningful realworld context, the learner's idea must drive their capabilities in the learning process: And, the teacher become more flexible as a knowledge facilitator [5]. In [6, 8], Learning is the constant parameter and time, a variable in such setting. Constructivist learning is dynamic, learner-centered (not curriculum centered) and with socially-mediated activities split into learning acquisition and participation metaphors $[12,13]$. This model stresses a setting in which knowledge is generated based on a learner's ability to construct it from his environ. In [14], There four dimensions namely: trivial, radical, social and cultural constructivism.

Science-tech in Africa and Nigeria has continued to gain wide acceptance. Though, un-shackling itself off its inherent challenges require international caliber to help put African trajectories in perspective by comparing them with other experiences the world over. With a unified objective, science-tech as influenced by constructivism, will posses these challenges to the educational system namely $[6,14,15]$ :

a. Nativism: Cultural constructivism projects racism and distorts the fundamental unity of science. It views knowledge as meanings and how a user conveys an idea in different languages. It conveys meanings of various forms-even when referring to the same event, insofar the grammatical structures of spoken language differs. It also believe meanings are connected with linguistics-though science posits meaning as objective states of nature that transcends linguistic boundaries. Hence, all spoken language must construct its own periodic table for atoms, molecule configurations and recreate nature to suit their cultural and/or linguistic boundary. Cultural constructivism's nativism and applied sciences' empiricism are too parallel and may never meet at the table of globalization.

b. Poor globalization is often misconstrued not as co-construction of knowledge but as nativism. The global network ensures unification of science via interaction exchange of concepts and ideas, innovations and skills of persons scattered around the world. It does not urge individuals and research to be localized and restricted by culture. It encourages competition and knowledge dissemination. Cultural constructivism in science education thus, is faced with the challenge of capacity building, establishing research networks and advancing dialogues within Africa and the world over.

c. Territorialism: The false belief that only monkeys live in Africa-limits research and scientific discourse on the realities of the continent to impose territorialism of knowledge-making it a criminal assumption of cultural constructivism to think that generation of knowledge do not transcend cultural boundaries. Ideas formed from different world cultures must be globalized due to predominance of idea similarities, over its differences. These similarities by virtue of its many appearances can then imprintsin the mind of expertswhile, the changing individual differences fails to attain fixity and performance. Inventors like Newton, Faraday etc transcended ethnicity. Curriculum and its material must become deterritorialized.

Tech-rich, constructivist education provides learners with large data. The emergence of big-data continues to transform methods to education. The challenge to both educators and learners, is the shift from the practiced norms. Constructivist education eliminates statewide assessment promoted by the conventional model via aligned test. Also, fund shortage and adaptation issue to rapid changes by both teachers and students must be continuously resolved-with a role change in teachers' duties. This shift require teachers' retraining, role redefinition and acculturation to effect this systemic change-even though it be slow [16].

Constructivist principles include [17]: (a) active learning consists of meaning construction as well as in constructing system for the meanings, (b) language impacts what is learned, (c) learning is a social activity 
rippled with connections a learner makes with others, (d) learning time allows the learner to revisit principles, reflect and adapt them to problems faced as much as often, (e) learning is contextual as the learner cannot learn isolated facts and/or theories in abstract, devoid real world, (f) motivation is needed to effectively help a learner help us know how the acquired knowledge can be put to use, $(\mathrm{g})$ knowledge construction is mentalsince it happens in the mind of the learner, and (i) knowledge is important as we cannot comprehend new ideas without previous or prior knowledge to build on $[18,19]$.

This new paradigm shift, design and transformed education will yield the following [20, 21]:

a. Shift from whole class to smaller groups

b. Teachers coach weaker students rather than all

c. Students become actively engaged, cooperative and less competitive

d. Students learn differently than simultaneously

e. Integrate visual/verbal thinking rather than primacy of verbal thinking as in traditional class.

Education stakeholders requires motivation to adapt to this practice which shifts from the paradigm they know [22, 23]. The constructivist class structure is more fragmented with revised teacher roles to emancipate students. Thus, this paradigm requires staff retraining to re-defined teachers' role and why they do what this job as in Figure 1.

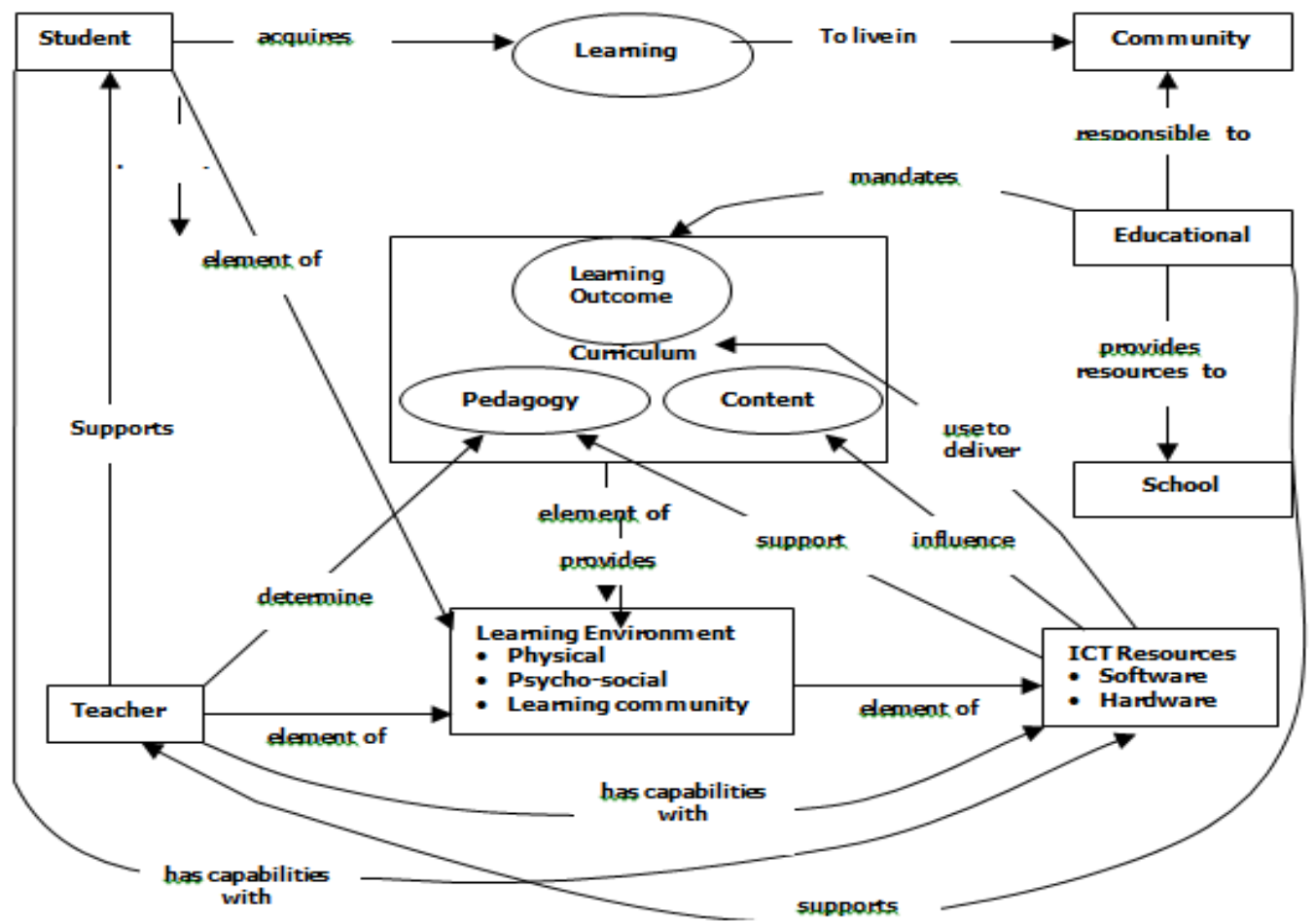

Figure 1. Relationship between the learning environment Entities

ICT equipped citadels varies in their preparedness and adoption, for teachers and students alike. Also, students' capability to acquire the needed flexibility to adapt is proportional to the infrastructure level, available ICT settings in school, students' attitude, teachers' role acceptance and attitude to change, among other. An ICT-rich schools, is gratned access to large volume of data and other resources. The integration of ICT results in educational reforms in the learning process. Educators who advocate such reforms opines a learning platform that advances constructivism [6] with a need for students to develop high thinking skill and avoid the pitfalls in traditional school models [7,8]. With ICT media-assisted models, constructivism allows learning to take effect as a learner completes tasks [9, 24-28].

Technology creates an ideal learning. Thus, [10] ICT rich class creates a learner-centered environ with a belief that they learn more from what they do/think. We must take care, not to allow the dynamic nature of technology overshadow the enduring nature of learning and ever-increasing knowledge base about learning $[4,7]$. Thus, [11] the concept of constructivism as one in which a learner has the ability to actively construct knowledge as he learns. It also emphasizes knowledge as a construction of reality in the learner's 
mind because knowledge is a dynamic adaptation towards an interpretation of experience. It supports many interpretations to reality based on knowledge constructed from experience and media-rich class. It focuses on knowledge construction rather than consumption-as the learner constructs data from experiences and mental beliefs, interpreting events accomplished outside the mind. We thus see the world we describe rather than describing the world we see. When integrated across curriculum, it provides appropriate level of difficulty due to its tasks that are of real world relevance with engaged-learning and teachers becoming knowledge guides [12-17].

E-learning is the way out of this perennial limitation of space, time, and location. E-learning promises various merits and alternatives to the traditional classroom learning, helping societies to move toward a vision of life-long and on-demand learning [29, 30]. This learning will improve access to higher education by teaming candidates who are denied access into conventional varsities. The national universities commission (NUC) is committed to ensure that the open and distance learning (ODL) mode is encouraged in Nigerian university system (NUS), as an alternative to the face-to-face mode. This is in consonance with the national policy on education which has recognized the place of open and distance learning in achieving constant education [31-33]. A goal of Nigeria open and distance education is to provide access to quality education and equity in educational opportunities for those who otherwise would have been denied. However, in spite of the NUC's commitment, few universities in Nigeria have fully implemented e-learning and open distance learning [34].

U-learning is one in which a learner can smoothly commence the learning process anytime, anywhere [35-37]. It is based on ubiquitous computing, normally associated with a large number of small electronic devices such as smart mobile phones, contactless smart cards, handheld terminals, sensor network nodes, radio frequency identifications etc - used in our daily lives [38-42]. U-Learning is not constrained by schedules and physical spaces; It is embedded in our everyday living. It is pervasive, ongoing and affective. It takes learning out of traditional structure. U-learning offers data access seamlessly [43] and the next evolution of e-learning. Its main feats are permanency, accessibility, immediacy, interactivity, situating of instructional activities and adaptability [44, 45]. U-learning has the potential to revolutionize education, removing many of the physical constraints in the traditional learning. It offers great innovation to education (alternative) delivery, allowing for personalization and customization to student needs [46-49].

Will constructivism yield the needed difference via engaged-learning and knowledge transfer to students in their own context as applicable to knowledge? To what extent will this method be effective to boost student's learning, performance and achievement? The study seeks to: (a) what extent are textbooks readable in classes which they are proposed/approval?, and (b) Is proposed textbook approved by Delta State Education Board more readable than standard textbooks used in privately owned schools?

The study is designed to investigate learning between a constructivist and non-constructivist class as well as help ascertain the readability of textbooks used in the teaching and learning of computer studies (as proposed) in Delta State senior secondary school level at the various levels. The study: (1) seek alternative exemplary educational practices, (2) showcase an outcome that describes group or individual adoption patterns of technology in learning, and (3) link technology integration, quality students learning and staff development.

\section{RESEARCH MATERIALS AND METHODS}

\subsection{Data gathering and sampling}

In extending [11] using [50] framework to ascertain the readiness of these universities to adapt elearning and stay ahead the pandemic currently ravaging the world-we conducted a systems analysis and design for the study. All universities in Nigeria as recognized by the national university commission (NUC) are categorized into: federal, state and private universities. Names and links to their websites were obtained from the NUC website. To explore the webometrics ranking and footprint on the web of Nigerian universities. Thus, varsity web contents were explored and analyzed to determine the level of implementation of e-learning by each of the universities. Where links to e-learning portals were provided on the university's website, such links were tested. The number of undergraduate programs available for e-learning was examined. The utilization of learning management systems and the features of such systems were checked. Through literature survey, the general issues confronting the adoption and implementation of elearning, mobile learning, and ubiquitous learning were then determined, paying particular attention to the problems responsible for the slow pace of implementation of these technologies in Nigeria. These factors were analyzed and categorized to propose a model for the implementation of e-learning, m-learning, and ulearning in Nigeria [10-11].

Table 1 shows the summary of the analysis of e-learning status in the universities in Nigeria. The analysis shows that twenty-eight percent of the universities in Nigeria have links to e-learning portals in the 
universities websites but only fourteen percent of the universities have actually adopted e-learning with functional e-learning links.

Table 1. Summary analysis of e-learning status in Nigerian Universities 2019

\begin{tabular}{|c|c|c|c|c|c|c|}
\hline $\begin{array}{l}\text { Varsities } \\
\text { Category }\end{array}$ & $\begin{array}{c}\text { Total No of } \\
\text { Varsities }\end{array}$ & $\begin{array}{l}\text { Varsities with } \\
\text { Link e-Portals }\end{array}$ & $\begin{array}{c}\text { No using e- } \\
\text { learning }\end{array}$ & $\begin{array}{c}\% \text { using e- } \\
\text { learning }\end{array}$ & $\begin{array}{l}\text { No expected to adopt e- } \\
\text { learning/In-progress }\end{array}$ & $\begin{array}{c}\% \text { using e- } \\
\text { learning }\end{array}$ \\
\hline Federal & 43 & 40 & 23 & 13 & 40 & 23 \\
\hline State & 48 & 35 & 17 & 10 & 39 & 23 \\
\hline Private & 79 & 76 & 76 & 44 & 77 & 45 \\
\hline Total & 170 & 151 & 151 & 67 & 156 & 91 \\
\hline
\end{tabular}

(Source: Ojugo and Yoro, 2020)

\subsection{Experimental model: the extended three-tier learning model}

The proposed learning model consists of three interacting tiers: the analysis tier, the decision tier, and the incremental implementation tier as shown in Figure 2. Each tier consists of a set of operations and deliverables.

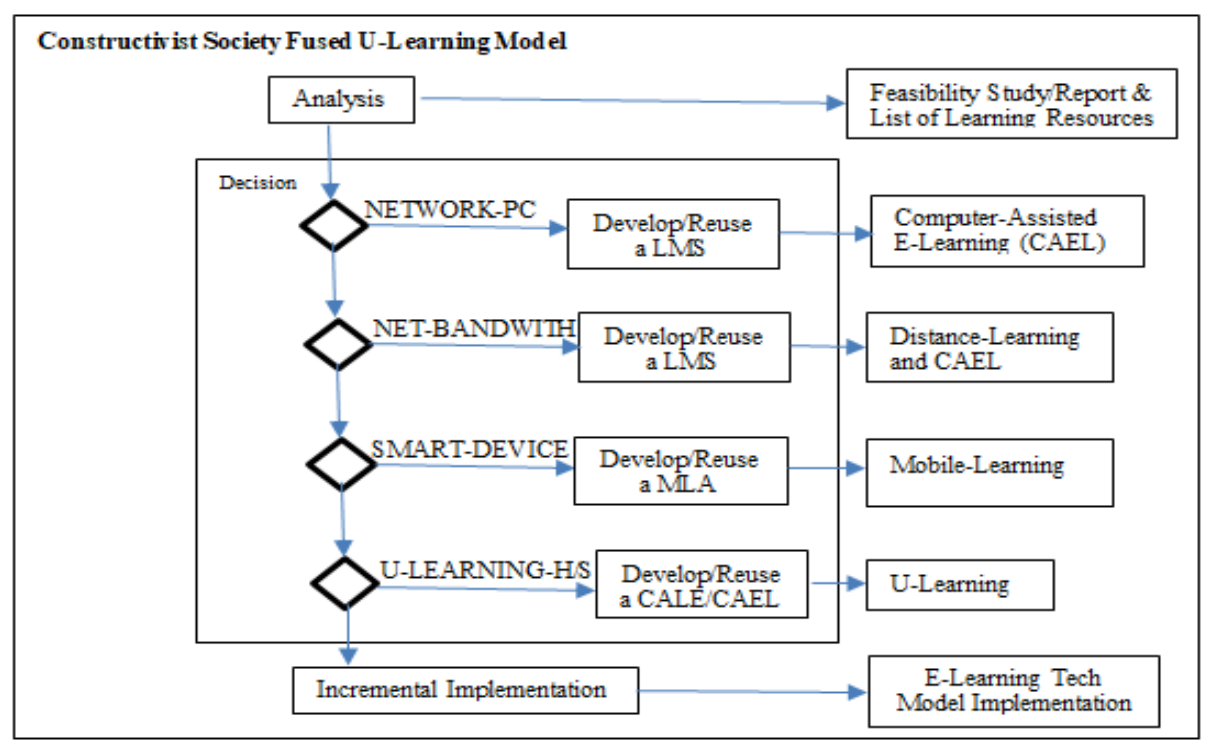

Figure 2. Constructivist Society fused with the U-Learning Model of Oyemade et al 2016

In the analysis tier, the level of e-readiness of the institution is determined via feasibility study on the availability of e-learning resources. The available e- and u-learning equipments are documented. Availability of adequate bandwidth in the university community is determined. A survey on students' access to smartphones and others are assessed as well as students' familiarity cum usage with the ubiquitous equipments. We exit at the preparation of feasibility reports, list of e-learning, m-learning, and u-learning resources available.

Decision tier uses a decision criteria to determine actions implemented based on deliverables of the analysis tier. The first step is to find out from the list and feasibility report of the analysis tier, if the local area network and personal computers are available (a condition denoted "NETWORK-PC". If Yes, then develop or reuse a Learning Management System, train the staff, and implement computer assisted e-learning.

The second step is to ascertain if Internet connection and adequate bandwidth are available. This condition is described as "NET-BANDWITH." If internet connection and adequate bandwidth are available in addition to local area network, personal computers, and laptops, then develop or reuse a Learning Management System and then implement distance learning using an accepted distance learning model.

The third step is to ascertain whether students are familiar with smartphones, tablets, etc (a condition is described as "SMART-DEVICE". If Yes and they possess these items, then develop or reuse a mobile learning application (MLA), create awareness on m-learning, and implement m-learning. 
The fourth step is to ascertain the availability of the main hardware components of a u-learning space. This condition is described as "U-LEARNING-H/S." If the hardware components of u-learning space are available, then develop/reuse a context-aware learning environment (CALE) and implement u-learning. The third tier (i.e. implementation tier), uses incremental implementation that depends on the aspect of the learning technologies that can be accommodated at any time. The whole process is repeated until all the learning technologies have been implemented.

\section{RESULT FINDINGS AND DISCUSSION}

Samples were selected for constructivist-rich and non-constructivist groups for each institution via stratified sampling adopting the extended model above (to minimize error in results with fair representation). Sample of 4 senior lecturers were selected via stratified sampling from the various varsities (federal, state and private institutions). Pedagogical practice and extent of involvement will determine if a group exhibits feats or not. Its outcome is a measure of students'assessment/performance via mean and standard deviation as:

\subsection{ICT integration impact on students achievement}

Table 2 shows differences in students' mean score achievement. At post-test, constructivist student group had higher mean scores than their counterpart as attributed to exposure in using ICT in learning. Table 3 shows a significant difference as male students in the non-constructivist group exhibited higher attitude to media literacy than their counterpart. This can be a result of initial technophobia of their being introduced to new pedagogical, learning scenario.

Table 2. Mean score of student achievement in two groups

\begin{tabular}{cccccc}
\hline \multicolumn{2}{c}{ Table 2. Mean score of student achievement in two groups } \\
\hline Groups & \multicolumn{2}{c}{ Pre-Test } & \multicolumn{2}{c}{ Post-Test } \\
Experimental or Constructivist & 720 & 13.85 & 3.12 & 21.43 & 4.15 \\
Control or Non constructivist & 720 & 10.63 & 2.56 & 19.40 & 3.50 \\
\hline
\end{tabular}

Table 3. Student attitude in the two groups

\begin{tabular}{cccc}
\hline Groups & Number & Male & Female \\
\hline Experimental or Constructivist & 720 & 10.1663 & 9.9823 \\
Control or Non constructivist & 720 & 11.0001 & 10.0011 \\
\hline
\end{tabular}

Result shows ICT-rich class supports technology literacy, high student emancipation from teachers, increased motivation for engaged learning, improves academic performance (test assessment), and interdependence that allows learners to develop requisite skills associated with time and resource management, concentration, self-discipline, attention to defined task and ability to follow instructions. However, role change and skills needed to support the paradigm should be carefully introduced considering the perception of the learners and their poor past experiences. It was also observed that students use ICT in different ways because more access requires greater personal responsibility that is lacking in some students.

\subsection{ICT-Integration impact on teacher role change and attitude}

Table 4 shows significant difference in the experimental group as teachers are more at home with the idea that such courses must and should be taught in technology-rich classes. ICT-driven education requires a complete change in attitude though teachers remain instructional leaders to aid interaction and motivation, as well as retain their established influence in directing class activities. Thus, teachers must reflect on ICT's impact on their roles and on the learner. Teachers adoption thereof, must note the issues of curriculum review, learning materials, new student roles and behaviour-as they seek to provide information avccess that leads to engaged experimentation and increased students' interest. That, learning requires more collaboration from all stakeholders with proper planning, coordination, skills development and knowledge of the adapted ICT. Teachers should be apprised that such setting will yield greater productivity with a pedagogy that is: (1) active and learner-centered, (2) more collaborative, (3) learning based on great knowledge access and source, and (4) learning that creates the need for interdependence in learners. 
Table 4. Teacher attitude in the two groups

\begin{tabular}{cccc}
\hline Groups & Number & Male & Female \\
\hline Experimental or Constructivist & 720 & 14.663 & 9.660 \\
Control or Non constructivist & 720 & 11.001 & 8.912 \\
\hline
\end{tabular}

\subsection{ICT impact on learning and classroom}

ICT offers new learning methods with teachers relying on knowledge to improve decisions of how and what the classroom space looks like and to improve its overall effectiveness. Its positive impact includes: (a) class-size reduction, (b) increased learning time, (c) improved performance via cost-effective computer aided instructions, and (d) gains with ICT-rich learning mediated via components like revised curriculum, redefined teacher roles and hybrid pedagogy. ICT enabled adequate investigation with available large data access, and tools to analyze them as well as broaden knowledge. It allows engaged participation and proper assessment of class tasks. With increased engagement with curriculum-students create their own knowledge and posit/share their own ideas. Learning experiences and interaction will improve (online/offline). Overall, a learner-centered education will make students more responsive, assist in deeper levels of learning as well as improve students' advances of the theoretical framework in and of learning.

\subsection{ICT integration in the education system and sector}

Schools must provide requisite infrastructure to support ICT-based and constructivist-integrated learning. The needed requisites to support this includes [17]: (1) adapt tech to education goals, (2) technology to support curriculum, (3) in-service training of teachers and administrators, (4) provide teachers time to plan and learn how to integrate ICT, (5) access to appropriate technology, (6) administrative support for using the technology, and (7) technical support for usage of ICT. These falls into 5-areas namely [5]: (a) infrastructure provision, (b) schooling, (c) curriculum, (d) school design, organisation, policies and practices, and (e) technical support for teachers.

\subsection{ICT integration impact on curriculum}

Curriculum is a two-way relationship: (a) it helps to convey curriculum and (b) changes curriculum contents. ICT-rich, support learning is a function of its curriculum content and pedagogy practice-because, the contents are addressed via effective strategies that learning benefits from [5]. ICT impact on curriculum is seen from the perspective of: (i) declarative knowledge that describes events by specifying their properties therein, and (ii) procedural knowledge that focuses on processes needed to obtain results. It yields a dynamic model with visualization and analytic tools that seeks to change the nature and inquiry of accessing content. These changes effect on the nature of knowledge and acceptance of evidence. Thus, curriculum must remain relevant to societal needs-training learners that connect in meaningful and motivating ways as they apply these knowledge to their workplace and daily tasks-since at some stage, it becomes a trajectory needs to connect them with non-school discourses.

\section{SUMMARY AND CONCLUSION}

Results show that there is significant difference exhibited by mean scores of students and of teachers in constructivist group over counterparts in non-constructivist group. This confirms the view [5], that learning via the constructivist model paves way for meaningful, engaged learning and active participation and serves as motivational factor in learning. The rationale is whether in practice, it has positive impact and must lead to a system that decides what students, teachers and school, aims to achieve.

In $[23,24]$ notes that 3 main rationales as thus:

1) Education productivity: Ratio of output over input is the quantity/quality of learning demonstrated by the student over cost. With proper input selected, learning is optimized via increase outcome. Productivity cannot be based on the fact that ICT media are expensive to install-as cases may arise in where technology becomes the solution to a problem. If part of the curriculum is not completed for lack of technology, its associated outcome and productivity becomes zero.

2) Technological literacy; ICT helps to address problems in curriculum. Education technology is selected on the basis that it has best feats for implementing the curriculum, as there is always a two-way relationship between curriculum and educational technology. Firstly, policy makers decide what to learn (curriculum), after which technology and the method to be used is determined by the intended curriculum. Secondly, new technology adds new feats to curriculum contents; while making some contents obsolete.

3) Student's learning support: There are much potential for the use of computers in learning but whatever the rationale, requires a critical evaluation on the part of students. We must bear in mind these criteria to be met on the learner's part: (a) managing high quality educational programmes requires large amount of 
data, which teachers must effectively help students manage, (b) Access to resource materials linked to teaching and learning (online and offline), and (c) computer literacy.

The following recommendations were made:

1. Government must fund the integration and provide infrastructure support - as reform is not just about the provision of ICT equipment. It also involves the ribust enforcement of policies to aid these reforms.

2. Curricular reforms must be made to reflect ICT integration with reviews presented to the government for proper assessment/implementation.

3. Staff professional development scheme must be organized by administrators to equip and redirect teachers' focus to emancipate students. This retraining will aid teachers to better understand their new and expected role as well as will help them navigate a fully ICT integrated curricular.

This study contributes in four ways: (1) its outcome gives a description of individual and group adoption of technology for teaching/learning across the various educational levels, (2) images exemplary practices for teaching, learning and research; and (3) it links ICT integration, engaged students learning as well as staff professional development. Teachers and administrator having gained insight, must rise and equip themselves to make decision that will avert these problems, as they hold the keys to students success in this new education plan. Its significance is both theoretical and practical as it highlights the folowing:

a. Increases awareness/application of ICT theories-naming issue and challenges with widespread adoption of ICT in education and outcome of curricular across subject areas in schools.

b. Highlights an adoption mode documentation and feats of administrators/teachers willing to integrate ICT with the support of network facilities. Our results shows, use of shared data instrument for widespread access by both teachers and students, based on engaged learning and the stages of technology adoption, will form the basis for the next step in the planning and implementation processes at each school. A useful information to all stakeholders in educations.

c. Education mode will provide the much-needed images and efficacious integration for engaged learningas such knowledge is useful, at organizational and individual level for staff development and further research in such areas.

\section{REFERENCES}

[1] A.A. Ojugo., E.O. Okonta, A.O. Eboka., I.J.B. Iyawa., M.O. Yerokun., "Information and communication technology to aid constructivism as means for alternative delivery in Nigeria", West African J. Industrial \& Academic Res., vol. 5, no. 1, pp. 114-127, 2012.

[2] H.A. Rowe., "Learning with personal computers," Hawthorn: Australian Council for Educational Research, 1993.

[3] A.A. Ojugo., F.O. Aghware and E.O. Okonta, "Reengineering Nigerian Education via ICT", EBSU Sci. Edu., vol. 3, pp.15-21, 2005, ISSN: 0189-9015

[4] A.A. Ojugo., A.O. Eboka., "Assessing user satisfaction and experience on academic websites: a case of selected Nigerian Universities websites, Int. J. Tech \& Comp. Sci., vol. 10, no. 7), pp53-61, 2018, doi: 10.5815/ijitcs.2018.10.07

[5] A.A. Ojugo, F.O. Aghware and A.O. Eboka., "Role of ICT and CAI in Nigerian Education", J. Res. In Physical Sci., vol. 2, pp. 25-31, 2007.

[6] A.A. Ojugo, F.O. Aghware., E.O. Okonta., R. Igbunu and C.C. Onochie., "Constructivism aid teaching of computer science in Delta State", Nigeria, ASSEQEN, vol. 5, no. 2, pp. 122-127, 2008.

[7] R.W. Clouse and H.E. Nelson, "School reforms, learning and educational technology", J. Edu. Tech. Sys., vol. 28, no. 4, pp. 289-303, 2000.

[8] J. Campione, A.L. Brown and M. Jay, "Computers in the community of learners, Springer-Verlag, Berlin, 1990.

[9] D. Loader and L. Nevile., "Educational computing: resourcing the future", Incorp. Asso. of Registered Teachers of Victoria, VC, 1991.

[10] A.A. Ojugo., D.O. Otakore., "Redesigning academic website for better visibility and footprint: a case of Federal University of Petroleum Resources Effurun website", Network \& Communication Technologies, vol. 3, no. 1, pp. 33-44, 2018.

[11] A.A. Ojugo., O.D. Otakore., "Mitigating social engineering menace in Nigerian Universities", J. of Comp. Sci. \& Application, vol. 6, no. 2, pp. 64-68, 2018, doi: 10.12691/jcsa-6-2-2

[12] L.S. Vygotsky., "Mind in society, development of higher psychological processes", Harvard press, Cambridge, 1978.

[13] C. Glickman. "Pretending not to know what we know", J. Edu. Leadership, vol. 48, no. 8, pp. 4-10, 1991.

[14] J. Dewey, "Democracy and education", Free press, New York, 1966.

[15] Kurose, J. and Ross, K. "Computer Networking: A Top-Down Approach, “ 6th edn. ed. by Hirsch, M. and Snider, E. Boston: Pearson Education Limited, 2013.

[16] R.H. Strommen and G.A. Lincoln. "Role of constructivism in changing state of education, application at Montgomery school for children", J. Edu. Tech, vol. 32, 1-18, 1992.

[17] E. Vosniadou, "Implementing new education technologies", Princeton, New Jersey, 2004.

[18] BECTA, "Impact of Information and communication technologies on pupil learning and attainment," ICT in school 
research and evaluation series, no. 7, DfES, 2002.

[19] Committee on Development of Science Learning (Ed.), "How people learn: Brain, mind, experience and School", National Academy press, Washington DC, 2000.

[20] E. Decortes, "Learning with new information technologies in schools: perspectives from the psychology of learning and instruction," J. Comp. Aided Instru., vol 6, pp. 69- 87, 1990.

[21] A.L. Brown, “Advancement of learning," J. Edu. Researcher, vol. 23, no. 4, pp. 4-12, 1994.

[22] B. Collis, "Using information technology to create a new educational situation," UNESCO Congress on Edu. and Info., p. 19, 1989.

[23] T. Laferriere and R. Bracewell., "Benefits of using ICT for teaching and learning in K-12/13 classrooms," SchoolNet Canada, 1999, [online] www.schoolnet.ca/snab/e/reports/research.asp.

[24] C. Lankshear and I. Snyder., "Teachers and technoliteracy," Allen and Unwin, St. Leonards, NSW, 2000.

[25] O. Abonyi, "Cultural constructivism in science education: issues of $21^{\text {st }}$ century In Nigeria," NERDC: Lagos, vol. 12, no. 2, pp. 172-183, 2005.

[26] R.A. Yager., "Constructivism: an instructional strategy to reposition teaching and learning of mathematics in secondary schools," New York: Free press, 1991.

[27] P.C. Newhouse., "Impact of ICT on learning and teaching," McGraw Hill publication, New York, 2006.

[28] Y.U. Ilo, "New media for education and training", Ferlam publishers, Geneva, pp. 31-38, 2004.

[29] Zhang, D., J. L. Zhao, L. Zhou, J. Nunamaker. "Can E-Learning Replace Traditional Classroom Learning-Evidence and Implication of the Evolving E-Learning Technology." Communications of the ACM, vol. 47, no. 5, pp. 75-9, 2004.

[30] Zhang, D., L. Zhou, R. O. Briggs, and J. F. Nunamaker Jr. 2005. "Instructional Video in ELearning: Assessing the Impact of Interactive Video on Learning Effectiveness", Info \& Mgt. vol. 43, no. 1, pp. 15-27, 2004. doi:10.1016/j.im.2005.01.004.

[31] Yahiya, S., E. A. Arniza, and K. A. Jalil, "The Definition and Characteristics of Ubiquitous Learning: A Discussion." Int. J. Education and Development Using Information and Communication Technology, vol. 6, no. 1, pp. 117-27, 2010 .

[32] Atsumbe, B. N., E. Raymond, B. Enoch, and P. Duhu, "Availability and Utilization of E-Learning Infrastructures in Federal University of Technology, Minna." Journal of Education and Practice, vol. 3, no. 13, pp. 56-64, 2012.

[33] Aremu, D. R., B. P. Jacob, and P. M. Ogedebe, "Cloud Based E-Learning Model for Open and Distance Learning in Nigerian Universities." International Journal of Science and Research vol. 4, no. 3, pp. 1998-2006, 2015.

[34] Anene, J. N., H. Imam, and T. Odumuh, "Problem and Prospect E-Learning in Nigerian Universities." International Journal of Technology and Inclusive Education vol. 3, no. 2, pp. 320-7, 2014.

[35] Bomsdorf, B, "Adaptation of Learning Spaces: Supporting Ubiquitous Learning in Higher Distance Education." Mobile Computing and Ambient Intelligence: The Challenge of Multimedia. Accessed August 29, 2015. http://drops.dagstuhl.de/opus/volltexte/2005/

[36] Bonk, C. J, “The World is Open: How Web Technology is Revolutionizing Education”, San Francisco, 2009.

[37] Caceffo, R., and H. Vieira da Rocha, "Design and Model of a Ubiquitous Classroom Response System through Context Factors." Ubiquitous Learning: An International Journal, vol. 4, no. 3, pp. 61-71, 2012.

[38] Hwang, G. J., C. C. Tsai, and S. J. H Yang, "Criteria, Strategies and Research Issues of Context-Aware Ubiquitous Learning." Educational Technology and Society, vol. 11, no. 2, pp. 81-91, 2008.

[39] Karna, N. J., S. C. B. Nelaturu, R. Kambham, R. Parupalli, and K Mandula, "Blending Grid, Ubiquitous Computing and Web Technologies for Ubiquitous Learning." Ubiquitous Learning: An Int. Journal, no. 3, pp. 63-9, 2009.

[40] Chiaha, G. U., J. U. Eze, and F. O. Ezeudu, "Education Students' Access to E-Learning Facilities in Universities South-East of Nigeria." Information and Knowledge Management, vol. 3, no. 10, pp. 32-41, 2013.

[41] Dang, X.T., Howard, N., Raymon, L, "Factors Affecting Ubiquitous Learning from the Viewpoint of Language Teachers: Case Study from Vietnam." Ubiquitous Learning: An International J. vol. 4, no. 2, pp. 57-71, 2012.

[42] Deason, C., M. J. Campbell., R. Blanton, "How a Behavioral Socialization Approach to Learning Reduces Intellectual Development to Performance and Outcomes: Rationale for Teachers, Parents, and Learners to Utilize Ubiquitous Browser-Based Web 2.0 Platforms for Pedagogy.” Ubiquitous Learning: An International J. vol. 4, no. 4, p. 87, 2013.

[43] Moller, D. P. F., R. Hass, and H. Vakilzadian, "Ubiquitous Learning: Teaching Modeling and Simulation with Technology" Proc. of the 2013 Grand Challenges on Modeling and Simulation Conference, 24, Society for Modeling and Simulation International. Accessed August 29, 2015. http://dl.acm.org/citation.cfm?id=2557692.

[44] Ofuyatan, O., E. Opaluwa, and A. Adeola, "Challenges and Effects of E-Learning in the Development of Architecture and Engineering in Nigeria's Private Tertiary Institution.” Developing Country StudiesI, vol. 4, no. 23, pp. 130-4, 2014.

[45] Restrepo, C. , L. Pulido, R. A. Nuñez, G. Perez, C. Mejia, "Introduction to an Ubiquitous Learning Model to Assess the Ubiquity Level in Higher Education Institutions." Ubiquitous Learning: An Int. Journal, vol. 5, no. 2, pp. 1-15, 2013.

[46] Tarus, J. K., D. Gichoya, and A. Muumbo, "Challenges of Implementing E-Learning in Kenya: A Case of Kenyan Public Universities." International Review of Research in Open and Distributed Learning, vol. 16, no. 1, pp. 12041,2015

[47] Sakamura K., and N. Koshizuka, "Ubiquitous Computing Technologies for Ubiquitous Learning." Proceedings of the 2005 IEEE International Workshop on Wireless and Mobile Technologies in Education, pp. 11-20, 2005.

[48] Wen, J., K. Cheng, C. Chen, and Y. Hsieh, "A Study on the Application of Ubiquitous Learning Environment to English Learning in Elementary Schools." Universal Journal of Education and General Studies, vol. 2, no. 2, pp. 
53-65, 2013.

[49] Song, S. M, "E-Learning: Investigating students' acceptance of online learning in hospitality programs." $\mathrm{PhD}$ dissertation, Iowa State University, 2010.

[50] D. Oyemade., J. Akpojaro., A.A. Ojugo., R. Ureigho., F. Imouokhome., E. Omoregbee, "Three tier learn model for universities in Nigeria", J. of Tech. in Society, vol. 12, no. 2, pp9-20, 2016. [web]: https://jts.cgpublisher.com

\section{BIOGRAPHIES OF AUTHORS}

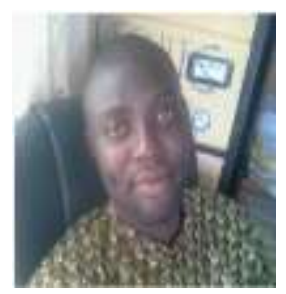

Arnold Adimabua Ojugo received BSc Computer Science from the Imo State University Owerri in 2000, MSc in Computer Science from the Nnamdi Azikiwe University Awka in 2005, and $\mathrm{PhD}$ in Computer Science from the Ebonyi State University Abakiliki in 2013. He currently lectures with the Department of Computer Science at the Federal University of Petroleum Resources Effurun, Delta State, Nigeria. His research interests: Intelligent Systems/Machine Learning, Data Security/IoT, and Graph Theory. He is an Editor with Progress for Intelligent Computation and Application, SceincePG etc. He is a member of: The Nigerian Computer Society, Computer Professionals of Nigeria and The International Association of Engineers. He is married to Prisca with five children.

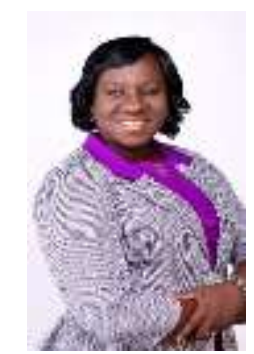

Rume Elizabeth Yoro received her BSc in Computer Science from the University of Benin Edo State in 2000, MSc in Computer Science from both Benson Idahosa University and the University of Benin respectively in 2009 and 2013. She currently lectures with the Department of Computer at the Delta State Polytechnic Ogwashi-Uku Nigeria. Her research interests: Network Management, Computer Forensics/IoT and Machine Learning. She is a member of: Computer Professionals of Nigeria, Nigerian CompuSociety, Computer Forensics Institute of Nigeria and Nigeria Women in Information Technolgy the International Association of Engineers. 